\title{
EVALUATION OF LEUKOCYTE ESTERASE REAGENT STRIPS TEST IN THE DIAGNOSIS OF SPONTANEOUS BACTERIAL PERITONITIS IN CHILDREN WITH CIRRHOSIS
}

\author{
Naser HONAR ${ }^{1}$, Bita GERAMIZADEH ${ }^{2}$, Seyed-Mohsen DEHGHANI', Gholamreza KALVANDI ${ }^{3}$, \\ Iraj SHAHRAMIAN ${ }^{3}$, Asghar RAHMANI ${ }^{4}$ and Hazhir JAVAHERIZADEH ${ }^{3}$
}

Received 16/3/2015 Accepted 27/4/2015

ABSTRACT - Background - Spontaneous bacterial peritonitis is defined as an ascetic fluid infection without an evident intra-abdominal surgically treatable source. Spontaneous bacterial peritonitis is one of the severe complications in patients with cirrhosis and ascites. Without early antibiotic treatment, this complication is associated with high mortality rate; therefore, early diagnosis and treatment of spontaneous bacterial peritonitis is necessary for survival. Leukocyte esterase reagent can rapidly diagnose the spontaneous bacterial peritonitis. Objective - This study aimed to find out the diagnostic accuracy of leukocyte esterase dipstick test for the diagnosis of spontaneous bacterial peritonitis. Methods - A single centered hospital-based cross-sectional study was conducted during July 2013 to August 2014 on children with cirrhotic liver disease and ascites who were admitted in the Department of Pediatric Gastroenterology in Nemazee Hospital affiliated to Shiraz University of Medical Sciences (Iran). All patients underwent abdominal paracentesis, and the ascitic fluid was processed for cell count, leukocyte esterase reagent strip test (Combiscreen SL10) and culture. Spontaneous bacterial peritonitis was defined as having a polymorphonuclear count $\left(\mathrm{PMN} \geq 250 / \mathrm{m}^{3}\right)$ in ascitic fluid. Sensitivity, specificity, positive predictive value and negative predictive value of leukocyte esterase test were calculated according to the formula. Results - Totally, 150 ascitic fluid sample of cirrhotic male patients (53.2\%) and their mean age (4.33 \pm 1.88 years) were analyzed. Biliary atresia $(n=44,29.4 \%)$ and idiopathic neonatal hepatitis $(n=29,19.3 \%)$ were the most frequent etiology of cirrhosis. Also, abdominal pain (68.6\%) and distension (64\%) were the most common presenting complaint. Of all cases, 41 patients $(27.35 \%)$ were diagnosed to have spontaneous bacterial peritonitis $\left(\mathrm{PMN} \geq 250 / \mathrm{mm}^{3}\right)$. Sensitivity and specificity of leukocyte esterase reagent test according to PMNs $\geq 250 \mathrm{~mm}^{3}$ were $87.80 \%$ and $91.74 \%$, also on ascitic fluid culture results were $88.23 \%$ and $77.44 \%$. Positive predictive value and negative predictive value of this test in PMNs $\geq 250 \mathrm{~mm}^{3}$ were $80 \%$ and $95.23 \%$ and in cases with positive culture $33.33 \%$ and $98.09 \%$ were obtained, respectively. Efficiency of leukocyte esterase reagent test in diagnosing spontaneous bacterial peritonitis, according to PMNs $\geq 250 \mathrm{~mm}^{3}$ and culture results were $90.66 \%$ and $78.66 \%$. Conclusion - The leukocyte esterase strip test may be used as rapid test for diagnosis of spontaneous bacterial peritonitis due to its high diagnostic validity.

HEADINGS - Peritonitis. Ascites. Ascitic fluid. Neutrophils. Esterases. Leukocyte esterase. Child. Liver cirrhosis.

\section{INTRODUCTION}

Spontaneous bacterial peritonitis (SBP) is one of the most common and severe complication of cirrhotic patients $^{(5,18,21)}$. Without early therapeutic intervention, mortality of SBP is about $20 \%-40 \%{ }^{(22)}$. The characteristic of the SBP is spontaneous infection of the ascetic fluid without an intra-abdominal source of infection $^{(10,20,25)}$. SBP patients usually have symptoms like fever, abdominal pain, impaired renal function, hypertension and progression to encephalopathy.
SBP prevalence declines about 30\%-40\% due to early diagnosis and treatment with broad-spectrum antibiotics $^{(8,11)}$. Despite impressive advances in medical care of patients with advanced liver disease in recent decades, SBP is still a common problem and cause of death of bacterial infection in these patients ${ }^{(1,24)}$. Most methods used in the diagnosis of SBP in the clinical practice are based on demonstration of polymorphonuclear (PMN) in the peritoneal fluid. Globally, irrespective of culture, the $\mathrm{PMN} \geq 250 / \mathrm{mm}^{3}$ in ascitic fluid is known as the best marker of peritonitis ${ }^{(5,14,22)}$.

Declared conflict of interest of all authors: none

Disclosure of funding: no funding received

${ }^{1}$ Gastroenterohepatology Research Center, Nemazee Teaching Hospital, School of Medicine, Shiraz University of Medical Sciences, Shiraz, Iran; ${ }^{2}$ Shiraz Transplant Research Center Shiraz University of Medical Sciences, Shiraz, Iran' ${ }^{3}$ Fellow of Pediatric Gastroenterology Nemazee Teaching Hospital, School of Medicine, Shiraz University of Medical Sciences, Shiraz, Iran; ${ }^{4}$ Student Research committee, School of medicine, Ilam University of Medical Sciences, Ilam. Iran.

Correspondence: Gholamreza Kalvandi. Dept. of Pediatric Gastroenterology d, Nemazee Teaching Hospital, School of Medicine, Shiraz University of Medical Sciences, Shiraz, Iran. Email: pezeshk1351@yahoo.com 
However, the diagnosis of SBP takes hours by cell counter method. On the other hand, limitations in the adequate and necessary laboratory facilities and the long duration of ascitic fluid cultures are the causes of the delay in diagnosis of SBP with ascetic fluid cultures. This condition implies the necessity of a rapid diagnostic test. Leukocyte esterase reagent (LER) dipstick is a test that removes this time limit, such that the diagnosis of peritonitis is possible with this test within a few minutes ${ }^{(2,17)}$. Recently, this test has been used for rapid diagnosis of infection in any type of body fluid, such as pleural fluid, ascetic fluid, and cerebrospinal fluid $(\mathrm{CSF})^{(6,17,23)}$. The LER basic principle is interaction between leukocyte esterase and esterifies compound in the reagent strip yielding a violet azoic dye ${ }^{(15,22)}$. Further studies in diagnosis of SBP using LER test have been performed on adults but a comprehensive study of the performance of this test has not been performed in children. Using this test, physicians may perform a timely diagnosis, clinical management and appropriate treatment. This study aimed to find out the diagnostic accuracy of leukocyte esterase dipstick test for the diagnosis of spontaneous bacterial peritonitis.

\section{Study design}

A single centered hospital-based cross-sectional study was conducted during July 2013 to August 2014 on children with cirrhotic liver disease and ascites who were admitted in the Department of Pediatric Gastroenterology in Nemazee Hospital affiliated Shiraz University of Medical Sciences (Iran), the major referral center in the field of hepatology and liver transplantation in children in Iran. This study was approved by the Ethics Committee of the University and written consent was obtained from all parents after informing them about this study. All the parents were asked to sign the informed consent. Patients who had received antibiotics within the previous week within or outside the hospital for any reason, patients with a history of surgery for any reason in the past month, hematemesis, primary renal dysfunction, secondary bacterial peritonitis, peritonitis carcinomatosis, pancreatic ascites, subjects with portal hypertension due to malignancy or tuberculosis were also excluded.

Patients aged less than 19 years with cirrhosis of the liver, regardless of the gender, were selected as the study population. A total of 150 cirrhotic patients were included in the current study. Demographic and clinical information was collected through questionnaires, oral interview, and careful physical examination. Differential cell count and cytology were examined with a conventional optical microscope. The diagnosis of cirrhosis in our study was according to histological, clinical and sonographic findings of the liver. In this study, ascitic fluid PMN count $\geq 250 / \mathrm{mm}^{3}$ with or without a positive culture for ascetic fluid (without contiguous source of intra-abdominal infection) was considered as standard for diagnosis of SBP.

\section{Paracentesis}

All patients underwent abdominal paracentesis under aseptic condition. With the use of aseptic techniques, $20 \mathrm{~mL}$ of ascetic fluid was sent for routine biochemical and culture test. The reagent strip (Combiscreen SL10, Analyticon, Germany) was immersed in $5 \mathrm{~mL}$ of ascetic fluid placed on a dry and clean container as described by the manufacturer for identification of LER test. After 2 minutes, the reagent strip was read comparing the color of the leukocyte reagent strip area with the colorimetric 5-grade scale depicted on the bottle. The test is based on the esterase activity of the granulocytes present in the ascetic fluid that reacts with an ester releasing 3-Hydroxy-5-phenyl-pyrrole. This reaction causes a color change in an azo dye (purple). Results of leukocyte esterase reagent strip were compared with ascetic fluid PMN cell count.

\section{Diagnostic criteria}

The diagnosis of SBP was based on a PMN $\geq 250 / \mathrm{mm}^{3}$ in ascitic fluid, irrespective of a positive ascetic fluid culture and clinical signs of SBP, and an absence of intra-abdominal sources of infection or inflammation ${ }^{(16)}$.

\section{Statistical analysis}

Data are presented as means \pm SD for quantitative variables and as frequencies for qualitative variables the exact $95 \%$ confidence interval for each statistic was calculated from the binominal distribution. The sensitivity, specificity, positive predictive value (PPV) and negative predictive value (NPV) were calculated according to their standard formulas. SPSS statistical software version 14.0 (SPSS Inc., Chicago, IL, USA) was used for data analysis.

\section{RESULT}

In total, the data of 150 patients were analyzed. Seventy-nine $(52.3 \%)$ patients were male and $71(43.7 \%)$ female $(P=0.362)$. Mean \pm SD age of patients was $4.88 \pm 4.37$ years (range 1 month to 18 years). Mean age of females was $4.92 \pm 3.49$ years (range 2 months to 18 years) and that of males was $8.83 \pm 4.73$ years (range 1 month to 16 years) $(P=0.341)$.

The most common symptom in subjects was abdominal pain $(68.6 \%)$, distension $(64 \%)$ and fever $(58.6 \%)$, respectively. The prevalence of symptoms of vomiting, irritability, loss of consensus and poor feeding was $29.3 \%, 23.3 \%, 13 \%, 3 \%$, $26 \%$, respectively. The most common etiology of patients was biliary tract artesia $(27.6 \%)$ followed by idiopathic neonatal hepatitis $(19.3 \%)$ and lowest prevalence of autoimmune hepatitis $(2 \%)$ and congenital hepatic fibrosis $(4.6 \%)$, (Table 1$)$.

In our study, the positive and negative LER test separately based on number of PMNs and culture were evaluated. Positive and negative results of leukocyte esterase test in terms of the number of PMNs were shown in Table 2. According to $\mathrm{PMN} \geq 250 / \mathrm{mm}^{3}$ of ascetic fluid, $41(27.35 \%)$ patients were diagnosed with SBP (Table 2). Among them, leukocyte esterase test was negative in five patients $(12.2 \%)$ and in 36 $(87.8 \%)$ patients it was positive. Moreover, in $109(72.6 \%)$ cases we obtained the PMNs $<250 \mathrm{~mm}^{3}$ with no diagnosis of SBP. Of them, $100(91.8 \%)$ patients showed negative LER 
TABLE 1. Characteristics of patients

\begin{tabular}{|c|c|}
\hline Variable & \\
\hline Sex (male/female, \%) & $79(52.3 \%) / 71(43.7 \%)$ \\
\hline Age (mean $\pm \mathrm{SD}$, year $)$ & $4.37 \pm 1.88$ \\
\hline Clinical symptoms & \\
\hline Vomiting (\%) & $44(29.3 \%)$ \\
\hline Abdominal pain $(\%)$ & $103(68.6 \%)$ \\
\hline Distension (\%) & $96(64 \%)$ \\
\hline Irritability (\%) & $35(23.3 \%)$ \\
\hline Loss of consciousness (\%) & $20(13.3 \%)$ \\
\hline Fever $(\%)$ & $88(58.6 \%)$ \\
\hline Poor feeding $(\%)$ & $39(26 \%)$ \\
\hline Etiology of cirrhosis (\%) & \\
\hline Idiopathic neonatal hepatitis (\%) & $29(19.3 \%)$ \\
\hline Biliary artesia $(\%)$ & $44(29.4 \%)$ \\
\hline Cryptogenic cirrhosis (\%) & $8(5.3 \%)$ \\
\hline Wilson disease (\%) & $14(9.3 \%)$ \\
\hline Fulminant hepatitis (\%) & $12(8 \%)$ \\
\hline Tyrosinemia (\%) & $8(5.3 \%)$ \\
\hline Congenital hepatic fibrosis (\%) & $7(4.7 \%)$ \\
\hline Autoimmune hepatitis (\%) & $3(2.0 \%)$ \\
\hline Others (\%) & $25(16.7 \%)$ \\
\hline
\end{tabular}

TABLE 2. Positive and negative result of LER test based on number of PMNs and culture

\begin{tabular}{lccc}
\hline \multirow{2}{*}{ Variable } & \multicolumn{2}{c}{ LES test result } & \multirow{2}{*}{ Total } \\
\cline { 2 - 3 } & Negative & Positive & \\
\hline PMN count $<250 \mathrm{~mm}^{3}$ & $100(91.8 \%)$ & $9(8.2 \%)$ & $109(72.7 \%)$ \\
PMN $\geq 250 / \mathrm{mm}^{3}$ & $5(12.2 \%)$ & $36(87.8 \%)$ & $41(27.3 \%)$ \\
Culture of fluid & & & \\
Negative & $103(77.5 \%)$ & $2(11.8 \%)$ & $105(70 \%)$ \\
Positive & $30(22.5 \%)$ & $15(88.2 \%)$ & $45(30 \%)$
\end{tabular}

LER: leukocyte esterase reagent; PMN: polymorphonuclear; LES: leukocyte esterase. test result and $9(8.2 \%)$ revealed a positive test result. Of the total of 150 patients, $105(70 \%)$ had a negative test result and $45(30 \%)$ had a positive leukocyte esterase (LES) test result.

Among the total patients (150 patients), ascitic fluid cultures in $17(11.3 \%)$ were positive and in $133(88.6 \%)$ patients were negative. Of the 17 patients with positive cultures, 2 $(11.7 \%)$ patients and $15(88.2 \%)$ patients were found to have positive and negative result tested for leukocyte esterase, respectively. Also, of the 133 patients with negative culture results, $103(77.5 \%)$ patients and $30(22.5 \%)$ patients were found to be positive and negative in leukocyte esterase, respectively. Sensitivity and specificity of LER test on the basis of $\mathrm{PMN} \geq 250 / \mathrm{mm}^{3}$ were $87.80 \%$ and $91.74 \%$.

Also, based on ascitic fluid culture results, sensitivity and specificity were obtained $88.23 \%$ and $77.44 \%$, respectively. The PPV and NPV of this test based on the PMN $\geq 250 / \mathrm{mm}^{3}$ and positive cultures were obtained $80 \%, 95.23 \%$ and $33.33 \%$, $98.09 \%$, respectively. In total, accuracy of LER test in detecting SBP on PMN $\geq 250 / \mathrm{mm}^{3}$ was $90.66 \%$ and based on the culture results it was $78.66 \%$ (Table 3 ).

TABLE 3. Sensitivity, specificity, PPV, and NPV of the LES test in SBP

\begin{tabular}{lcc}
\hline Variable & PMN $\geq 250 / \mathrm{mm}^{3}$ & Culture positive \\
\hline Sensitivity & $\% 89.80$ & $\% 87.00$ \\
Specificity & $\% 91.74$ & $\% 77.44$ \\
PPV & $\% 80$ & $\% 33.33$ \\
NPV & $\% 95.23$ & $\% 98.09$ \\
Accuracy & $\% 90.66$ & $\% 78.66$ \\
\hline
\end{tabular}

PPV: positive predictive value; NPV: negative predictive value; LES: leukocyte esterase; SBP: spontaneous bacterial peritonitis; PMN: polymorphonuclear.

\section{DISCUSSION}

Spontaneous bacterial peritonitis is one of the important causes of mortality and morbidity of cirrhotic patients ${ }^{(19)}$. As the result, early diagnosis and treatment of these patients is essential in improving their clinical outcomes. Methods routinely used in the diagnosis of SPB have a time limit and a few hours to a few days are needed for diagnosis ${ }^{(20)}$. Also, measuring the number of ascitic PMN count is done by hematological methods using optical microscopy and manual counting. Although the PMN count of ascitic fluid is used as the gold standard for the diagnosis of SBP, this method is laborious and time-consuming. Spending a long time in diagnosis of SBP can cause an advancement in the stage of the disease and clinical implications. On the basis of these problems, considerable efforts have been made in recent years to develop an alternative test for a more rapid diagnosis of SBP. Leukocyte esterase enzyme has been shown as an 
important marker for PMN cell activity ${ }^{(3,9)}$. The efficacy of LER test for diagnosis of SBP has been reported in previous studies $^{(4,13,18,26,28,29)}$. Leukocyte esterase was used for urine analysis first, but recently it has been found to be useful across a wide range of body fluid infections ${ }^{(2,17)}$.

This study was conducted to evaluate the accuracy of LES test for diagnosis of SBP in cirrhotic children. According to $\mathrm{PMN} \geq 250 / \mathrm{mm}^{3}$, SBP was diagnosed in $41(27.35 \%)$ patients. Of these, the leukocyte esterase test in five (12.1\%) patients was negative and in $36(87.8 \%)$ patients was positive. Also, in $109(72.7 \%)$ patients PMNs $<250 \mathrm{~mm}^{3}$ with no SBP; $100(91.7 \%)$ patients had negative and $9(8.2 \%)$ had a positive LER test result. Therefore in this study, sensitivity, specificity, PPV and NPV of LER test in diagnosing SBP were $95.23 \%, 80 \%, 91.74 \%$ and $87.80 \%$, respectively. Also, based on ascitic fluid culture results, sensitivity, and specificity, PPV and NPV of LER test was obtained 88.23\%, $77.44 \%, 33.33 \%$ and $98.09 \%$, respectively. Although several studies have been conducted on the use of leukocyte esterase test in SBP, the results of these studies vary. In a study by Farahmand et al., nine patients with cirrhosis were studied and sensitivity, specificity, positive and negative predicate value for all of patients were derived $100 \%$ respectively ${ }^{(7)}$. Other studies have been done on adults, each reporting various reporting sensitivity and specificity. For example, in a study by Torun et al. performed on 63 consecutive adult patients with cirrhotic ascites, 15 subjects showed SBP. The sensitivity, specificity, PPV and NPV of the leukocyte esterase reagent strips were $93 \%, 100 \%, 100 \%$, and $98 \%$, respectively ${ }^{(27)}$. In another study done by Vanbiervliet et al. on 72 patients with cirrhosis, nine patients included were diagnosed with SBP, and LER test was positive in all cases with $100 \%$ sensitivity and specificity ${ }^{(28)}$. Butani et al. used LER test to diagnose SBP in 136 patients. The sensitivity, specificity, PPV and NPV value at this study were obtained $83 \%, 99 \%, 91 \%$, and $98 \%$ respectively ${ }^{(3)}$. Following other studies on adults, Khatwani and colleagues reported the sensitivity, specificity, PPV, NPV of leukocyte esterase dipstick test to diagnose SBP $92 \%, 95 \%, 96 \%$, and $90 \%$, respectively in ninety four patients with cirrhosis ${ }^{(12)}$. Although several studies have been conducted on the use of LER test in SBP, the results of these studies are varied. Variation in the results of these studies can be partly explained by the use of different brands of reagent strips and the use of different cutoff points for positivity. The majority of studies have examined the use of leukocyte esterase testing in the diagnosis of peritonitis in adult. So far, only one study has been conducted by Farahmand et al. ${ }^{(7)}$. using LER test in the diagnosis of SBP in children.
Our study is the first study carried out with a large sample size on the accuracy of LER test in diagnosing SBP in children. The mean age of the patients was 4.88 years (range 1 month to 18 years). As mentioned, in our study, accuracy of LER tests in detecting SPB was $90.66 \%$. There is a great potential in using LER test for diagnosis of SBP in children. This test is easy, does not require expertise, is rapid, can be performed bedside with a low cost, and has high sensitivity and specificity for diagnosis of SBP. Also, saving time at diagnosis of SBP leads to rapid start of antibiotic therapy. LER test is also useful in determining the effectiveness of antibiotic therapy.

\section{CONCLUSION}

In conclusion, LER test strips is a very sensitive, specific and very rapid identification method for diagnosis of SBP in children with cirrhosis specifically. This is a rapid bedside test that is easy to use and can be performed efficiently in order to speed up the bedside diagnosis of this clinical entity. It fits easily into the work flow of a routine gastroenterology department and can be conducted in settings that do not have the facilities to carry out biochemical and bacteriological tests for diagnosis of SBP. In addition, a positive test result should be an indication for initiation of empirical treatment, and negative results should exclude SBP. Finally, LER test can be used extensively in paracentesis as a screening test to exclude ascitic fluid infection in children.

\section{ACKNOWLEDGMENTS}

This paper was issued from fellowship thesis of Dr. Gholamreza Kalvandi and supported by research affairs of Shiraz University of Medical Sciences. The authors gratefully thank the laboratory personnel and Vice Chancellor of Researches and Technology for their valuable help on this study. This work was financially supported by Shiraz University of Medical Science. The authors would like to thank Dr. Nasrin Shokrpour at Center for Development of Clinical Research of Nemazee Hospital for editorial assistance.

\section{Authors' contributions}

Honar N: main idea and supervisor of thesis. Geramizadeh B: laboratory analysis and quality control and supervisor of thesis. Dehghani SM: revision of manuscript and data collection. Kalvandi G: writing proposal and data collection. Shahramian I: data collection and revision of manuscript. Rahmani A: writing the draft and data analysis. Javaherizadeh $\mathrm{H}$ : literature search and revision of manuscript. 
Honar N, Geramizadeh B, Dehghani SM, Kalvandi G, Shahramian I, Rahmani A, Javaherizadeh H. Avaliação de tiras reagentes de teste de esterase de leucócitos no diagnóstico de peritonite bacteriana espontânea em crianças com cirrose. Arq Gastroenterol. 2015,52(3):195-9.

RESUMO - Contexto - A peritonite bacteriana espontânea é definida como uma infecção do fluido ascítico sem evidente origem intra-abdominal cirurgicamente tratável. A peritonite bacteriana espontânea é uma das complicações graves em pacientes com cirrose e ascite. Sem tratamento antibiótico precoce, esta complicação é associada com alta taxa de mortalidade. Portanto, o diagnóstico precoce e tratamento de peritonite bacteriana espontânea são necessários para a sobrevivência. O reagente de esterase de leucócitos pode rapidamente diagnosticar a peritonite bacteriana espontânea. $\boldsymbol{O b}$ jetivo - Este estudo teve como objetivo descobrir a acurácia diagnóstica do teste com tiras de esterase de leucócitos para o diagnóstico de peritonite bacteriana espontânea. Métodos - Um estudo transversal hospitalar unicêntrico foi realizado entre julho de 2013 e agosto de 2014 em crianças com cirrose hepática e ascite que foram admitidas no Departamento de Gastroenterologia Pediátrica no Hospital de Nemazee afiliado à Universidade de Ciencias Médicas de Shiraz (Irã). Todos os pacientes foram submetidos a paracentese abdominal, e o líquido ascítico foi processado para contagem de células, teste de tira de reagente de esterase de leucócitos (Combiscreen SL10) e cultura. Peritonite bacteriana espontânea foi definida como tendo uma contagem de polimorfonucleares ( $\mathrm{PMN} \geq 250 / \mathrm{m}^{3}$ ) no líquido ascítico. Sensibilidade, especificidade, valor preditivo positivo negativo do teste de esterase de leucócitos foram calculados de acordo com a fórmula. Resultados - Foram analisados um total de 150 amostras de líquido ascítico de pacientes cirróticos; $(53,2 \%)$ eram do sexo masculino e sua média de idade (4,33 $\pm 1,88$ anos). A atresia biliar $(n=44,29,4 \%)$ e hepatite neonatal idiopática $(n=29,19,3 \%)$ foram as etiologias mais frequentes de cirrose. Além disso, dor abdominal $(68,6 \%)$ e distensão $(64 \%)$ foram as queixas mais comuns de apresentação. De todos os casos, 41 (27,35\%) foram diagnosticados com peritonite bacteriana espontânea (PMN $\left.2250 / \mathrm{mm}^{3}\right)$. A sensibilidade e especificidade do teste de reagente de esterase de leucócitos segundo PMN $\geq 250 \mathrm{~mm}^{3}$ foi de $87,80 \%$ e $91,74 \%$ e, para os resultados de cultura de líquido ascítico, de $88,23 \%$ e $77,44 \%$. Valor preditivo positivo e valor preditivo negativo do teste em PMN $\geq 250 \mathrm{~mm}^{3}$ foi de $80 \%$ e $95,23 \%$ e em casos com cultura positiva 33,33\% e 98,09\%, respectivamente. A eficiência do teste de reagente esterase de leucócitos no diagnóstico de peritonite bacteriana espontânea, de acordo com resultados de $\geq 250 \mathrm{~mm}^{3}$ e cultura PMN, foi de $90,66 \%$ e 78,66\%. Conclusão - O teste de tiras de esterase de leucócitos pode ser usado como um teste rápido para diagnóstico de peritonite bacteriana espontânea, devido a sua alta validade diagnóstica.

DESCRITORES - Peritonite. Ascite. Líquido ascítico. Neutrófilos. Esterases. Leucócitos. Criança. Cirrose hepática.

\section{REFERENCES}

1. Arvaniti V, D’Amico G, Fede G, Manousou P, Tsochatzis E, Pleguezuelo M, Burroughs AK. Infections in patients with cirrhosis increase mortality four-fold and should be used in determining prognosis. Gastroenterology. 2010;139(4):124656.

2. Azoulay E, Fartoukh M, Galliot R, Baud F, Simonneau G, Le Gall JR, Schlemmer B, Chevret S. Rapid diagnosis of infectious pleural effusions by use of reagent strips. Clin Infect Dis. 2000;31(4):914-9.

3. Butani RC, Shaffer RT, Szyjkowski RD, Weeks BE, Speights LG, Kadakia SC. Rapid diagnosis of infected ascitic fluid using leukocyte esterase dipstick testing. Am J Gastroenterol. 2004;99(3):532-7.

4. Castellote J, Lopez C, Gornals J, Domingo A, Xiol X. Use of reagent strips for the rapid diagnosis of spontaneous bacterial empyema. J Clin Gastroenterol. 2005;39(4):278-81.

5. Chinnock B, Afarian H, Minnigan H, Butler J, Hendey GW. Physician clinica impression does not rule out spontaneous bacterial peritonitis in patients undergoing emergency department paracentesis. Ann Emerg Med. 2008;52(3):268-73.

6. Evans LT, Kim WR, Poterucha JJ, Kamath PS. Spontaneous bacterial peritonitis in asymptomatic outpatients with cirrhotic ascites. Hepatology. 2003;37(4):897-901.

7. Farahmand F, Eshagh Roze M, Shams S, Ghajarzadeh M, Mohammadi B. Diagnosis of spontaneous bacterial peritonitis in children by reagent strips. Acta Med Iran. 2013;51(2):125-8.

8. Hoefs JC, Runyon BA. Spontaneous bacterial peritonitis. Dis Mon. 1985;31(9):1-48.

9. Jacobs JA, De Brauwer EI, Cornelissen EI, Drent M. Correlation of leukocyte esterase detection by reagent strips and the presence of neutrophils: a study in BAL fluid. Chest, 2000;118(5):1450-4.

10. Jepsen P, Vilstrup H, Møller JK, Sørensen HT. Prognosis of patients with liver cirrhosis and spontaneous bacterial peritonitis. Hepatogastroenterology. 2003;50(54):2133-6.

11. Khan J, Pikkarainen P, Karvonen AL, Mäkelä T, Peräaho M, Pehkonen E, Collin P. Ascites: aetiology, mortality and the prevalence of spontaneous bacterial peritonitis. Scand J Gastroenterol. 2009;44(8):970-4.

12. Khatwani NR, Chhutto MA, Abro HA, Habib-ur-Rahman, Shaikh MA Diagnostic validity of leukocyte esterase dipstick test for diagnosis of spontaneous bacterial peritonitis in cirrhotic patients. J Ayub Med Coll Abbottabad. 2011;23(1):51-4.

13. Kim DY1, Kim JH, Chon CY, Han KH, Ahn SH, Kim JK, et al. Usefulness of urine strip test in the rapid diagnosis of spontaneous bacterial peritonitis. Liver Int. 2005;25(6):1197-201.

14. Koulaouzidis A, El-Ramli R, Gasem J, Saeed AA. Leukocyte esterase reagent strips for spontaneous bacterial peritonitis: what now? Ann Hepatol. 2008;7(3):255-6
15. Kutter D, Figueiredo G, Klemmer L. Chemical detection of leukocytes in urine by means of a new multiple test strip. J Clin Chem Clin Biochem. 1987;25(2):91-4.

16. Moore KP, Wong F, Gines P, Bernardi M, Ochs A, Salerno F, et al. The management of ascites in cirrhosis: report on the consensus conference of the International Ascites Club. Hepatology. 2003;38(1):258-66.

17. Moosa AA, Quortum HA, Ibrahim MD. Rapid diagnosis of bacterial meningitis with reagent strips. Lancet. 1995;345(8960):1290-1.

18. Nousbaum JB, Cadranel JF, Nahon P, Khac EN, Moreau R, Thévenot T, et al. Diagnostic accuracy of the Multistix $8 \mathrm{SG}$ reagent strip in diagnosis of spontaneous bacterial peritonitis. Hepatology. 2007;45(5):1275-81.

19. Parsi MA, Atreja A, Zein NN. Spontaneous bacterial peritonitis: recent data on incidence and treatment. Cleve Clin J Med. 2004;71(7):569-76.

20. Rerknimitr R, Rungsangmanoon W, Kongkam P, Kullavanijaya P. Efficacy of leukocyte esterase dipstick test as a rapid test in diagnosis of spontaneous bacterial peritonitis. World J Gastroenterol. 2006;12(44):7183-7.

21. Rimola A, García-Tsao G, Navasa M, Piddock LJ, Planas R, Bernard B, Inadomi JM. Diagnosis, treatment and prophylaxis of spontaneous bacterial peritonitis: a consensus document. International Ascites Club. J Hepatol. 2000;32(1):142-53.

22. Runyon BA, McHutchison JG, Antillon MR, Akriviadis EA, Montano AA Short-course versus long-course antibiotic treatment of spontaneous bacterial peritonitis. A randomized controlled study of 100 patients. Gastroenterology. 1991;100(6):1737-42.

23. Sam R, Sahani M, Ulozas E, Leehey DJ, Ing TS, Gandhi VC. Utility of a peritoneal dialysis leukocyte test strip in the diagnosis of peritonitis. Artif Organs. 2002;26(6):546-8.

24. Tandon P, Garcia-Tsao G. Bacterial infections, sepsis, and multiorgan failure in cirrhosis. Semin Liver Dis. 2002;28(1):26-42.

25. Thanopoulou AC, Koskinas JS, Hadziyannis SJ. Spontaneous bacterial peritonitis (SBP): clinical, laboratory, and prognostic features. A single-center experience. Eur J Intern Med. 2002;13(3):194-8.

26. Thévenot T, Cadranel JF, Nguyen-Khac E, Tilmant L, Tiry C, Welty S, Merzoug N. Diagnosis of spontaneous bacterial peritonitis in cirrhotic patients by use of two reagent strips. Eur J Gastroenterol Hepatol. 2004;16(6):579-83.

27. Torun S, Dolar E, Yilmaz Y, Keskin M, Kiyici M, Sinirtas M, et al. Evaluation of leukocyte esterase and nitrite strip tests to detect spontaneous bacterial peritonitis in cirrhotic patients. World J Gastroenterol. 2007;13(45):6027-30.

28. Vanbiervliet G, Rakotoarisoa C, Filippi J, Guérin O, Calle G, Hastier P, et al. Diagnostic accuracy of a rapid urine-screening test (Multistix8SG) in cirrhotic patients with spontaneous bacterial peritonitis. Eur J Gastroenterol Hepatol. 2002;14(11):1257-60.

29. Wisniewski B, Rautou PE, Al Sirafi Y, Lambare-Narcy B, Drouhin F, Constantini $\mathrm{D}$, et al. [Diagnosis of spontaneous ascites infection in patients with cirrhosis: reagent strips]. Presse Med. 2005;34(14):997-1000. 